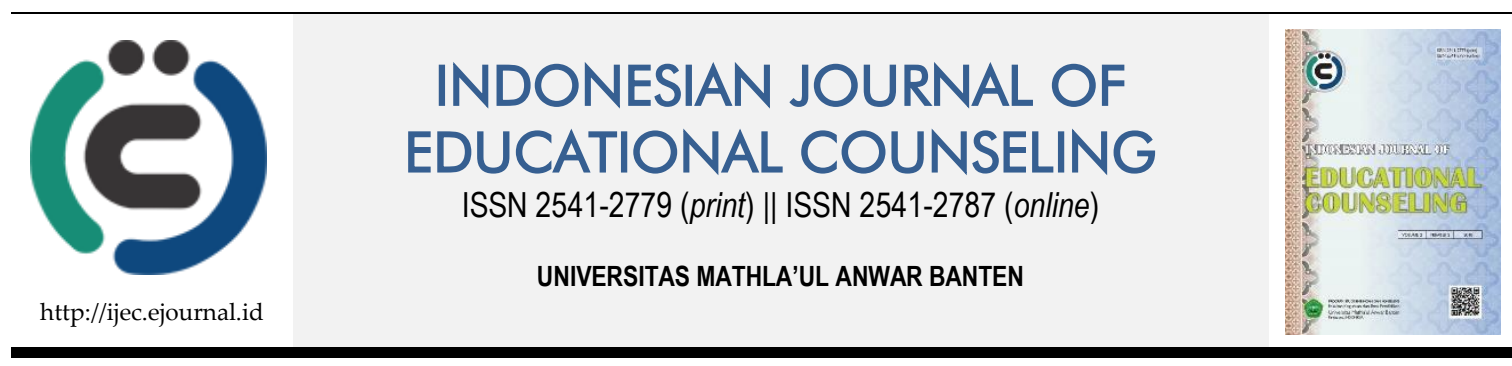

Theoretical/Conceptual Article

\title{
Konseling Konseptual: Sebuah Tinjauan Filosofis
}

\author{
Sri Astutik ${ }^{1}$
}

${ }^{1}$ Universitas Negeri Malang

\begin{tabular}{|c|c|}
\hline ARTICLE INFO & ABSTRACT \\
\hline $\begin{array}{l}\text { Article History: } \\
\text { Received 26.05.2018 } \\
\text { Received in revised } \\
\text { form } 14.06 .2018 \\
\text { Accepted } 19.07 .2018 \\
\text { Available online } \\
\text { 24.07.2018 }\end{array}$ & $\begin{array}{l}\text { Counseling is a process of giving help done by an expert (called counselor) to } \\
\text { the individual who experienced a problem (called counselee) which leads to the } \\
\text { overcoming problems facing him. Counseling serves as an effort to change, } \\
\text { prevent or increase the potential of life. This literature study contains a } \\
\text { description of the counselor's professional concepts in providing counseling } \\
\text { services covering the meaning of counseling, counseling parameters, } \\
\text { counseling and philosophy, counseling conditions and the effects of the } \\
\text { professional counselor as well as the characteristics of a professional counselor } \\
\text { which is seen based on the effectiveness of a helper. }\end{array}$ \\
\hline
\end{tabular}

DOI: $10.30653 / 001.201822 .42$

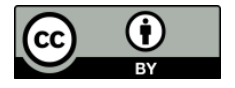

This is an open access article distributed under the terms of the Creative Commons Attribution 4.0 International License, which permits unrestricted use, distribution, and reproduction in any medium, provided the original work is properly cited. () 2018 Sri Astutik.

\section{PENDAHULUAN}

Situasi global membuat kehidupan semakin kompetitif dan membuka peluang bagi manusia untuk mencapai status dan tingkat kehidupan yang lebih baik. Hal ini menimbulkan dua dampak yang sangat berpengaruh dalam kehidupan manusia, adapun dua dampak tersebut adalah dampak positif dimana hal ini mendorong manusia untuk terus berpikir, dan meningkatkan kemampuan, sedangkan dampak yang lain adalah dampak negatif dimana hal in dapat dilihat dari semakin banyaknya konflik, tingkat stress, kecemasan dan frustasi yang terjadi di kalangan masyarakat. Semakin meningkatnya tingkat masalah yang dihadapi manusia, maka dibutuhkan sebuah kegiatan yang dapat membantu masyarakat dalam mengatasi masalahnya, kegiatan tersebut adalah layanan konseling yang dilakukan oleh seorang konselor.

Perkembangan keilmuan konseling memiliki sejarah yang panjang, di Mesopotamia (Irak), Persia (Iran), dan Mesir, para tokoh agama seperti pendeta kuno melakukan konseling dengan menggunakan mantra-mantra kuno sebagai penyembuh. Menurut Gibson (dalam Lasan, 2015) sejarah perkembangan konseling pada manusia terjadi ketika nabi Adam mendapat konsekuensi akibat makan buah terlarang di Taman Firdaus.

${ }^{1}$ Corresponding author’s address: Universitas Negeri Malang. Email: radean08@gmail.com. 
Menurut Habsy (2017b) konseling sudah ada sejak Ki Lurah Semar memberikan Konseling pada arjuna yang sedang mengalami konflik batin. Bentuk konselor primitif pada masa lalu diparktikkan oleh kepala suku, tabib, dukun, peramal yang dianggap mampu untuk menenangkan hati, atau memberikan prediksi pada masa depan. Meskipun memiliki sejarah panjang namun konsep konseling tetap sulit untuk dijelaskan dikarenakan kurangnya kejelasan publik karena banyak praktisi modern menggunakan label konselor.

Menurut Shertzer dan Stone (1980), konseling adalah proses interaksi yang memudahkan pemahaman bermakna diri dan lingkungan dan hasil dalam pembentukan dan atau klarifikasi tujuan dan nilai-nilai perilaku masa depan. Kemudian, ASCA (American School Counselor Association) (2012) mengemukakan bahwa konseling adalah hubungan tatap muka yang bersifat rahasia, penuh dengan sikap penerimaan dan pemberian kesempatan dari konselor kepada konseli, dimana konseelor mempergunakan pengetahuan dan keterampilannya untuk membantu konselinya dalam mengatasi masalah-masalahnya. Konseling adalah ilmu pengetahuan yang mandiri berakar pada filsafat dan agama yang didukung oleh ilmu pendidikan, psikologi, sosiologi, antropologi, budaya yang berintegrasi dan saling menguatkan (Habsy, 2017a).

Berdasarkan pendapat dari beberapa ahli, maka kita dapat mengambil kesimpulan bahwa konseling merupakan salah satu bentuk hubungan yang bersifat membantu, adapun makna bantuan disini adalah upaya untuk membantu orang lain agar ia mampu tumbuh kea rah yang dipilihnya sendiri, mampu memecahkan masalah yang dihadapinya dan mampu menghadapi krisis-krisis yang dialami dalam kehidupannya. Tugas seorang konselor adalah menciptakan kondisi-kondisi yang diperlukan bagi pertumbuhan dan perkembangan konseli.

\section{KAJIAN LITERATUR}

Hubungan dalam konseling bersifat interpersonal, kegiatan konseling terjadi dalam bentuk wawancara secara tatap muka antara konselor dengan konseli, dimana hubungan ini melibatkan semua unsure kepribadian yang meliputi: pikiran, pelrasaan, pengalaman, nilai-nilai, kebutuhan, harapan, dan lain-lain. Pada pelaksanaan kegiatan konseling kendaknya kedua belah pihak hendaknya menunjukkan kepribadian yang asli karena kegiatan konseling ini dilakukan dalam secara pribadi dan dilakukan dalam suasana rahasia. Keefektifan konseling sebagian besar ditentukan oleh kualitas hubungan antara konselor dengan konselinya, dimana bila dilihat dari segi konselor, kualitas hubungan inin bergantung pada kemampuannya dalam menerapkan tehnik-tehnik konseling serta kualitas kepribadian pribadinya untuk menjadi konselor yang professional.

Retorika penciptaan hubungan positif antara konselor dan konseli dalam proses konseling secara umum ditawarkan dengan model overview S-A-K-T-I, yaitu: (1) Sambut, menjalin hubungan yang hangat dan saling percaya, dilanjutkan dengan strukturing, (2) Aktif mendengarkan, mengeksplorasi dan mengumpulkan data tentang perilaku, pikiran, perasaan, kelemahan, kekuatan dan lingkungan yang ditengarahi memunculkan problematika, (3) Keinginan yang dituju, merumuskan tujuan konseling (perubahan perilaku, pikiran atau perasaan) yang ingin dicapai, (4) Teknik dan kerja, tinjauan alternatif pemecahan, aplikasi teknik bimbingan dan konseling, intervensi (perilaku, pikiran, dan perasaan), dan (5) Implementasi, penegasan komitmen, Perumusan tindakan efektif, implementasi \& tindakan nyata, evaluasi \& tindak lanjut (Habsy, 2017a). 
Menurut Cavanagh (1990) mengemukakan tujuh unsur kunci keberhasilan hubungan konseling sebagai berikut: (1) Petugas bantuan itu merupakan profesional yang terlatih, (2) Konselor memiliki hubungan dengan orang yang sedang dibantunya, (3) Seorang konselor profesional perlu memiliki keterampilan konseling dan kepribadian yang menunjang, (4) Seorang konselor membantu orang belajar, (5) Konselor berupaya membantu konseli berhubungan dengan dirinya sendiri secara lebih baik agar dapat menjadi lebih terintegrasi dan dapat menghindari konflik, (6) Konselor berupaya membantu konseli menuju pertumbuhan yang lebih produktif, (7) Konseling mengandung konotasi hubungan antara seorang konselor dengan seseorang yang meminta bantuan.

Artikel ini berisi uraian mengenai konsep profesional seorang konselor dalam memberikan layanan konseling mencakup makna konseling, parameter konseling, konseling dan filosofi, kondisi konseling dan efek yang ditimbulkan, serta karakteristik dari konselor professional, dimana hal ini dilihat berdasarkan keefektifan dari seorang penolong.

\section{DISKUSI}

\section{Parameter Konseling}

Konseling sebagai sarana perubahan atau perkembangan, dalam praktik konseling konselor diharapkan memfasilitasi perkembangan, mengatasi dan memecahkan masalah, serta berpartisipasi dalam membina hubungan dalam konseling dengan berusaha memahami pandangan konseli akan kehidupan dan alasannya seperti apa yang telah mereka lakukan (Depdiknas, 2008).

Pemahaman dan penghargaan yang tajam dalam hubungan konseling inilah yang akan memfasilitasi pemahaman kita sebagai konselor, dan konseli sebagai orang yang membutuhkan upaya penyembuhan, perkembangan atau perbaikan kehidupan. Seorang konselor yang baik harus memiliki kemampuan sebagai pendengar, memiliki kemampuan berkomunikasi dan berdiskusi dengan baik.

\section{Konseling dan Teori}

Secara umum teori konseling merupakan upaya untuk menjelaskan proses serangkaian kegiatan awal, mengembangkan dan mengakhiri kegiatan konseling. Empat tema yang dominan dalam teori konseling adalah kognitif, psikodinamik, humanistik, dan transpersonal. Ada penambahan satu tema dalam teori kepribadian, yakni pendekatan sistemik, namun dalam teori cybernetic (Corey, 2005). Teori konseling memiliki beberapa fungsi yakni sebagai pedoman untuk melayani dan menjelaskan bagaimana manusia belajar, berubah dan mengembangkan, berguna menjadi sebuah model untuk menormalkan fungsi manusia, serta apa yang harus terjadi dalam proses dan hasil konseling. Konselor menggunakan teori untuk mengatur informasi dan pengamatan, untuk menjelaskan konsep masalah konseli, dan menerapkan intervensi khusus dengan konseli (Gysbers, 2001).

Profesi konseling telah menyaksikan konvergensi meningkat diantara ahli teori dan realisasi berkembang bahwa tidak ada teori tunggal dapat menjelaskan atau cocok untuk semua klien (Corey, 2005). Hasilnya menunjukkan pandangan bahwa teori digunakan untuk melayani pengguna dan ketika tidak ada teori yang kompetibel maka prakrek yang dapat diterima. Hal ini dikenal sebagai pendekatan elektif integratif. Prochaska dan 
Norcross (2013) melaporkan bahwa lebih dari sepertiga memilih pendekatan elektik $(37 \%)$, teori eksistensial dan humanistik (13\%), teori kognitif $(10 \%)$, Client Center therapy $(8 \%)$, teori psikodinamik $(8 \%)$, teori sistemik $(7 \%)$, dan pendekatan behavior $(6 \%)$.

Menurut Corey (2005) mengemukakan tujuh elemen tentang konseling yang operatif untuk semua pendekatan teori yang utama:

1) Konseling melibatkan penangnan perasaan, pikiran, dan tindakan konseli.

2) Konseling melibatkan penerimaan dasar konseli persepsi dan perasaan, terlepas dari standar evaluatif.

3) Kerahasiaan dan privasi merupakan hal penting dalam pengaturan konseling.

4) Konseling bersifat sukarela. Konselor tidak pernah menggunakan paksaan sebagai sarana untuk memperoleh atau melanjutkan dengan konseli.

5) Konselor beroperasi dengan konservarif terhadap konseli

6) Salah satu keterampilan yang mendasari semua sistem konseling adalah komunikasi. Konselor dan konseli terus-menerus mengirim dan menerima pesan verbal dan nonverbal selama wawancara.

7) Konseling sebagai sebuah pengalaman lintas budaya, dan pengalaman multikultural.

\section{Konseling dan Filsafat}

Setiap orang memiliki pandangan filosofis tentang kehidupan. Beberapa orang melihat hidup sebagai urutan peristiwa dan pengalaman lebih dari yang mereka miliki. Pandangan hidup lain sebagai tantangan yang harus dianalisis dikendalikan dan diarahkan. Beberapa orang melihat tujuan hidup untuk menjadi prestasi dan pengembangan diri. Pandangan hidup sebagai proses yang harus dialami. Pandangan filosofis tentang kehidupan yang bervariasi, yang memungkinkan setiap individu memilih untuk mengidentifikasi pandangan yang tepat dan terbaik.

Teori konseling memiliki empat posisi filosofis,

1) Essensialisme, mengasumsikan bahwa manusia rasional dengan tujuan alami akan pendidikan, dan bahwa pemikir klasik adalah alasan utama repository.

2) Progresivisme, berkaitan dengan pertanyaan mendasar. Pengetahuan didasarkan pada hasil eksperimen, kebenaran diidentifikasi melalui konsekuensi, dan nilai-nilai yang relatif.

3) Eksistensialisme, memiliki makna kehidupan yang dapat ditemukan dalam individu, bukan dalam lingkungan atau peristiwa. Keabsahan (progresif) atau berfikir rasional (essensialisme) yang berarti individu memaknai keanggotaan mereka.

4) Postmodernisme, kesamaan antara postmodernisme dan eksistensialisme dalam hal ini, titik pentingnya adalah bahwa seseorang tidak akan pernah tahu realitas diri realitas di luar diri sendiri, dan karena itu harus fokus pada realitas pribadi (Corey, 2005)

Jadi, semua konselor memasuki profesi dengan beberapa variasi sudut pandang ini. Setiap filosofi konselor melihat bagaimana reaksi masalah konseli dan bagaimana masalah ini dapat di bahas. Demikian pula konseli memasukkan konseling dengan beberapa variasi dan sudut pandang, akan tercermin dalam cara mereka melihat masalah dan dianggap menjadi solusi yang layak. 


\section{Konseling dan Budaya}

Untuk mewujudkan pemahaman dan penerimaan terjadi dalam paraktik konseling, diharapkan konselor memahami faktor-faktor budaya yang telah membentuk dan terus mempengaruhi pandangan konseli. Konselor harus memahami sendiri atau pandangan dunia dan bagaimana dibentuk dengan cara yang mirip dengan pengalaman konseli bahkan ketika dua pandangan dunia secara substansial berada dari satu sama lain (Gysbers, N. C, 2001). Menurut Corey (2005) menyatakan tiga kemampuan utama yang diperlukan konselor dengan konseli dari budaya yang berbeda:

1) Memaksimalkan pikiran penuh, kata-kata dan perilaku yang memungkinkan komunikasi dalam suatu budaya tertentu.

2) Memaksimalkan pikiran penuh, kata-kata, dan perilaku yang memungkinkan komunikasi diberbagai ragam kelompok dan individu.

3) Kemampuan untuk merumus rencana dan tindakan yang menanggapi banyak kemunkinan yang ada dalam suatu budaya, dan kemudian untuk mengevaluasi tindakan.

\section{Karakteristik Penolong yang Efektif}

Berdasarkan hasi kajian literatur (Cavanagh, 1990; Surya, 2009; Yusuf, 2009; Habsy, Hidayat, \& Lasan, 2017) mengemukakan bahwa kualitas pribadi konselor ditandai dengan beberapa karakteristik sebagai berikut:

1) Pengetahuan Mengenai Diri Sendiri (Self-knowledge)

Disini berarti bahwa konselor memahami dirinya dengan baik, dia memahami secara nyata apa yang dia lakukan, mengapa dia melakukan itu, dan masalah apa yang harus dia selesaikan. Pemahaman ini sangat penting bagi konselor, karena beberapa alasan: a) Konselor yang memiliki persepsi yang akurat akan dirinya maka dia juga akan memilki persepsi yang kuat terhadap orang lain; b) Konselor yang terampil memahami dirinya maka ia juga akan memahami orang lain.

\section{2) Kompetensi (Competence)}

Kompetensi dalam karakteristik ini memiliki makna sebagai kualitas fisik, intelektual, emosional, sosial, dan moral yang harus dimiliki konselor untuk membantu konseli. kompetensi sangatlah penting, sebab konseli yang melakukan konseling akan belajar dan mengembangkan kompetensi-kompetensi yang diperlukan untuk mencapai kehidupan yang efektif dan bahagia. Adapun kompetensi dasar yang seyogianya dimilki oleh seorang konselor, yang antara lain: a) Penguasaan wawasan dan landasan pendidikan; b) Penguasaan konsep bimbingan dan konseling; c) Penguasaan kemampuan assesmen; d) Penguasaan kemampuan mengembangkan progaram bimbingan dan konseling; e) Penguasaan kemampuan melaksanakan berbagai strategi layanan bimbingan dan konseling; f) Penguasaan kemampuan mengembangkan proses kelompok; g) Penguasaan kesadaran etik profesional dan pengembangan profesi; h) Penguasaan pemahaman konteks budaya, agama dan setting kebutuhan khusus

3) Kesehatan Psikologis yang Baik

Seorang konselor dituntut untuk dapat menjadi model dari suatu kondisi kesehatan psikologis yang baik bagi konselinya, yang mana hal ini memiliki pengertian akan ketentuan dari konselor dimana konselor harus lebih sehat kondisi psikisnya daripada konseli. Karena apabila konselor kurang sahat psikisnya, maka ia akan teracuni oleh 
kebutuhan-kebutuhan sendiri, persepsi yang subjektif, nilai-nilai keliru, dan kebingungan.

4) Dapat dipercaya (Trustworthiness)

Konselor yang dipercaya dalam menjalankan tugasnya memiliki kecenderungan memilki kualitas sikap dan perilaku sebagai berikut: a) Memilki pribadi yang konsisten; b) Dapat dipercaya oleh orang lain, baik ucapannya maupun perbuatannya; c) Tidak pernah membuat orang lain kesal atau kecewa; d) Bertanggung jawab, mampu merespon orang lain secara utuh, tidak ingkar janji dan mau membantu secara penuh.

5) Kejujuran (Honest)

Kejujuran yang dimaksud di sini memiliki pengertian bahwa seorang konselor itu diharuskan memiliki sifat yang terbuka, otentik, dan sejati dalam pembarian layanannya kepada konseli. Jujur disini dalam pengertian memiliki kongruensi atau kesesuaian dalam kualitas diri aktual (real-self) dengan penilain orang lain terhadap dirinya (public self). Sikap jujur ini penting dikarenakan: a) Sikap keterbukaan konselor dan klien memungkinkan hubungan psikologis yang dekat satu sama lain dalam kegiatan konseling; c) Kejujuaran memungkinkan konselor dapat memberikan umpan balik secara objektif terhadap konseli.

6) Kekuatan atau Daya (Strength)

Kekuatan atau kemampuan konselor sangat penting dalam konseling, sebab dengan hal itu konseli merasa aman. Konseli memandang seorang konselor sebagi orang yang, tabah dalam menghadapi masalah, dapat mendorong konseli dalam mengatasi masalahnya, dan dapat menanggulangi kebutuhan dan masalah pribadi. Konselor yang memilki kekuatan venderung menampilkan kualitas sikap dan perilaku, seperti (a) dapat membuat batas waktu yang pantas dalam konseling, (b) bersifat fleksibel (c) Memilki identitas diri yang jelas

7) Kehangatan (Warmth)

Bersikap hangat itu adalah ramah, penuh perhatian, dan memberikan kasih sayang. Konseli yang datang meminta bantuan konselor, pada umumnya yang kurang memilki kehangatan dalam hidupnya, sehingga ia kehilangan kemampuan untuk bersikap ramah, memberikan perhatian, dan kasih sayang. Melalui konseling konseli ingin mendapatkan rasa hangat tersebut dan melakukan Sharing dengan konseling. Bila hal itu diperoleh maka konseli dapat mengalami perasaan yang nyaman.

\section{8) Pendengar yang Aktif (Active Responsiveness)}

Konselor secara dinamis telibat dengan seluruh proses konseling. Konselor yang memiliki kualitas ini akan: (a) mampu berhubungan dengan orang-orang yang bukan dari kalangannya sendiri saja, dan mampu berbagi ide-ide, perasaan, (b) membantu konseli dalam konseling dengan cara-cara yang bersifat membantu, (c) memperlakukan konseli dengan cara-cara yang dapat menimbulkan respon yang bermakna, (d) berkeinginan untuk berbagi tanggung jawab secara seimbang dengan konseli dalam konseling.

9) Kesabaran

Melalui kesabaran konselor dalam proses konseling dapat membantu konseli untuk mengembangkan dirinya secara alami. Sikap sabar konselor menunjukan lebih memperhatikan diri konseli daripada hasilnya. Konselor yang sabar cenderung menampilkan sikap dan perilaku yang tidak tergesa-gesa. 


\section{0) Kepekaan (Sensitivity)}

Kepekaan mempunyai makna bahwa konselor sadar akan kehalusan dinamika yang timbul dalam diri konseli dan konselor sendiri. Kepekaan diri konselor sangat penting dalam konseling karena hal ini akan memberikan rasa aman bagi konseli dan konseli akan lebih percaya diri apabila berkonsultasi dengan konselor yang memiliki kepekaan.

11) Kesadaran Holistik

Pendekatan holistik dalam bidang konseling berarti bahwa konselor memahami secara utuh dan tidak mendekatinya secara serpihan. Namun begitu bukan berarti bahwa konselor seorang yang ahli dalam berbagai hal, disini menunjukan bahwa konselor perlu memahami adanya berbagai dimensi yang menimbulkan masalah konseli, dan memahami bagaimana dimensi yang satu memberi pengaruh terhadap dimensi yang lainnya. Dimensi-dimensi itu meliputi aspek, fisik, intelektual, emosi, sosial, seksual, dan moral-spiritual.

\section{SIMPULAN}

Berbagai parameter proses konseling, berhubungan proses untuk teori konseling, filsafat, dan budaya, untuk menggambarkan tujuan konseling yang efektif, dan untuk menyoroti karakteristik pribadi utama konselor yang efektif. Hubungan konseling memiliki fitur tertentu yang membedakannya dari hubungan profesional atau sosial lainnya atau bahkan persahabatan. Salah satu fitur yang paling signifikan dari hubungan konseling adalah dimana seorang konselor profesional adalah seorang yang terlatih dan memiliki kemampuan untuk memberikan bantuan dengan cara yang kompeten dan terpercaya.

Meskipun terdapat berbagai karakteristik yang harus dipenuhi untuk mencapainya proses konseling yang baik, maka disarankan seorang calon konselor untuk dapat selalu membenahi dan memperbaiki dirinya kearah yang labih baik dan lebih mendekatkan diri pada yang Maha Kuasa serta memperkuat ilmu agama agar konseling yang dilaksanakan lebih berjalan dengan baik serta sesuai dengan kaidah-kaidah yang ada dalam agama. Selain itu, karakteristik konselor dapat mendorong timbulnya public trust terhadap diri seorang konselor.

\section{REFERENSI}

Cavanagh, M. E. (1990). The counseling experience: A theoretical and practical approach. Waveland Press.

Corey, G. (2005). Teori dan praktek konseling dan psikoterapi, (Terj. E. Koswara). Bandung: Refika Aditama.

Depdikas. (2008). Penataan pendidikan profesional konselor dan konseling dalam jalur formal. Jakarta: Depdiknas.

Gysbers, N. C. (2001). School guidance and counseling in the 21st century: Remember the past into the future. Professional School Counseling, 5(2), 96-106. 
Habsy, B. A. (2017a). Filosofi ilmu bimbingan dan konseling Indonesia. Jurnal Pendidikan (Teori dan Praktik), 2(1), 1-11.

Habsy, B. A. (2017b). Semar puppet counseling model. COUNS-EDU: The International Journal of Counseling and Education, 2(1), 19-24.

Habsy, B. A. (2017c). Seni memahami penelitian kualitatif dalam bimbingan dan konseling: Studi literatur. Jurnal Konseling Andi Matappa, 1(2), 90-100.

Habsy, B. A., Hidayah, N., \& Lasan, B. B. (2017). A literature review of indonesian life concept linuwih based on the teachings of adiluhung Raden Mas Panji Sosrokartono. Advances in Social Science, Education and Humanities Research, 128, 64-73.

Prochaska, J. O. (2013). Transtheoretical model of behavior change. In Encyclopedia of behavioral medicine (pp. 1997-2000). New York: Springer.

Surya, M. (2009). Psikologi konseling. Bandung: Maestro.

Yusuf, S. (2009). Program bimbingan dan konseling di sekolah. Bandung: Rizqi. 